\title{
Peningkatan Kualitas Usaha Mikro Kecil dan Menengah (UMKM) Melalui E-Commerce di Kampung Patin Kecamatan XIII Koto Kampar
}

\author{
Rohayati, Rafdeadi, Nur Alhidayatillah \\ 1,2,3Universitas Islam Negeri Sultan Syarif Kasim Riau \\ E-mail: rohayati@uin-suska.ac.id
}

\begin{abstract}
Abstrak
Kemajuan teknologi komunikasi dan informasi menjadikan manusia sangat bergantung kepada media, baik itu media mainstream ataupun media sosial. Salah satu pengaruh signifikan dari teknologi informasi adalah berubahnya sistem jual beli dari metode konvensional menjadi lebih modern, yaitu melalui internet atau biasa kita sebut dengan istilah e-commerce. Namun belum semua pelaku usaha kecil dan menengah memanfaatkan e-commerce untuk memaksimalkan penjualan, hal ini seperti yang dialami oleh petani ikan patin di Desa Koto Masjid Kec. XIII Koto Kampar. Pengabidan ini bertujuan untuk melatih pelaku usaha kecil dan menengah memanfaatkan media $e$ commerce dalam memasarkan produk mereka untuk meningkatkan pendapatan dan memperluas sasaran konsumen. Teknik pengabdian dilakukan secara langsung dan aplikatif, melalui metode presentasi (ceramah) dan pelatihan teknik e-commerce secara langsung (aplikatif), untuk selanjutnya dilakukan pendampingan. Peserta pelatihan adalah masyarakat yang memiliki usaha budidaya ikan patin di Desa Koto Masjid. Hasil dari pengabidan ini adalah masyarakat memiliki kemampuan untuk mengaplikasikan $e$ commerce sehingga dapat menjadi solusi untuk mengembangkan usaha yang telah mereka bangun, berinovasi dan tentu meningkatkan kesejahteraan para petani.
\end{abstract}

Kata Kunci: e-commerce, kampung Patin, kualitas, UMKM

\section{Abstract}

Advances in communication and information technology make humans very dependent on the media, be it mainstream media or social media. One of the significant effects of information technology is the change in the buying and selling system from conventional methods to more modern ones, namely through the internet or what we call e-commerce. However, not all small and medium-sized businesses have used e-commerce to maximize sales, this is as experienced by catfish farmers in Koto Masjid Village, Kec. XIII Koto Kampar. This service aims to train small and medium business actors to use e-commerce media in marketing their products to increase income and expand consumer targets. The service technique is carried out directly and is applicable, through the presentation method (lecture) and training on e-commerce techniques directly (applicative), for further assistance. The training participants are people who have a catfish farming business in Koto Masjid Village. The result of this service is that the community can apply e-commerce so that it can be a solution to develop the business they have built, innovate and of course improve the welfare of the farmers.

Keywords: e-commerce, kampung Patin, quality, UMKM 
Rohayati, Rafdaedi, Nur Alhidayatillah

Peningkatan Kualitas Usaha Mikro Kecil Menengah (UMKM) Melalui E-Commerce di Kampung Patin Kec.

XIII Koto Kampar

\section{Pendahuluan}

Penggunaan internet sebagai sarana jual beli mutlak dilakukan pada saat ini, dilihat dari jumlah pengguna internet yang ada di Indonesia mencapai lebih dari 160 juta jiwa. Tingginya jumlah pengguna internet di Indonesia menuntukkan bahwa peluang pasar lewat media daring sangat potensial. Melejitnya perkembangan teknologi komunikasi dan informasi menjadikan dunia usaha semangkin kompleks sehingga dibutuhkan metode, sarana serta media yang tepat untuk dapat bertahan ditengah perkembangan teknologi yang ada. Salah satu usaha yang dapat berkembang melalui penggunaan teknologi komunikasi dan informasi adalah UMKM.

Ditengah terpaan bonus demografi, dimana usia produktif mencapai 70\% dari total penduduk Indonesia. Maka, tantangannya terbesarnya adalah bertahan ditengah persaingan yang semangkin sulit. Kesulitan dalam memperoleh peluang bekerja salah satunya. Cara untuk mengantisipasi ini yaitu dengan mendirikan usaha sendiri sesuai dengan minat dan keahlian yang dimiliki. Hanya saja terkadang membuat usaha sesuai dengan minat dan keahlian ini terkadang terkendala oleh modal, pemasaran, bahan baku dan sebagainya.

Salah satu upaya menyiasati ini melalui jual beli online karena akan mempermudah akses kebutuhan bahan baku dan promosi ke semua wilayah Indonesia bahkan dunia. Supaya ini dapat terealisasi dengan baik, maka diperlukan pembinaan atau edukasi yang mumpuni bagi penggiat UMKM yang ada. Jika tidak ada edukasi tentang perkembangan dan pemanfaatan teknologi komunikasi, maka masyarakat tidak akan dapat bertahan hanya menggunakan cara-cara tradisional, untuk itu perlu pemahaman tentang pemanfaatan teknologi komunikasi guna menunjang perekonomian masyarakat di pedesaan.

Pemberdayaan masyarakat di pedesaan mutlak dilakukan untuk meningkatkan kualitas hidup masyarakat desa. Desa Koto Masjid merupakan salah satu desa yang ada di Kabupaten Kampar yang masih memerlukan peningkatan sumber daya manusia melalui UMKM yaitu pengelolaan ikan Patin Salai, sehingga diharapkan dengan memberikan edukasi kepada masyarakat tentang penggunaan internet sebagai media pendukung promosi UMKM maka akan meningkatkan kualitas hidup mereka.

Untuk itu diperlukan pelatihan pemanfaatan e-commerce bagi masyarakat yang memiliki usaha atau produk olahan, contohnya seperti yang terdapat di Kampung Patin Desa Koto Masjid. Masyarakat Kampung Patin belum memanfaatkan e-commerce secara optimal, sehingga diperlukan pelatihan pemanfaatan e-commece secara optimal untuk memaksimalkan penjualan dan meningkatkan penjualan sehingga kesejahteraan masyarakat juga akan meningkat.

Menurut Kotler dan Amstrong (2012), e-commerce adalah saluran online yang dapat dijangkau seseorang melalui komputer, yang digunakan oleh pebisnis dalam melakukan aktifitas bisnisnya dan digunakan konsumen untuk mendapatkan informasi dengan menggunakan bantuan komputer yang dalam prosesnya diawali dengan memberi jasa 
informasi pada konsumen dalam penentuan pilihan. Sementara, menurut Wong (2010)ecommerce adalah proses jual beli dan memasarkan barang serta jasa melalui sistem elektronik, seperti radio, televisi dan jaringan komputer atau internet.

Tujuan dari pelatihan e-commerce ini adalah untuk meningkatkan kemampuan pegiat UMKM dalam menggunakan teknologi komunikasi dan informasi. Selain itu diharapkan para petani ikan patin juga dapat mengembangkan kreativitasnya melalui tayangan maupun gambar yang diperoleh melalui media informasi. Dengan memasarkan produk melalui e-commerce maka diharapkan produk dapat dipasarkan seluas mungkin dengan biaya yang murah dan waktu yang fleksibel serta singkat. Kemampuan petani ikan patin juga akan bertambah dalam bentuk wawasan dan memahami peran serta fungsi teknologi informasi, internet, media sosial dan aplikasi komputer untuk administrasi perkantoran. Disamping itu, para petani ikan patin juga mampu menggunakan dan memanfaatkan jaringan komputer serta internet yang mencakup berbagai aplikasi dan fitur. Kegiatan ini melibatkan berbagai pihak terkait, seperti Dinas Koperasi Kabupaten Kampar, Kepala Desa Koto Masjid Kecamatan XIII Koto Kampar, serta masyarakat petani ikan patin sebagai sasaran dari kegiatan pelatihan e-commerce ini.

Pesatnya perkembangan teknologi komunikasi dan informasi menimbulkan dampak yang signifikan terhadap perkembangan toko online. Selain mudah, biaya yang dibutuhkan juga relaltif murah. Tidak jarang, toko online lebih bisa bertahan dibandingkan dengan toko offline. Masyarakat yang memiliki banyak kesibukan dan rutinitas menyukai hal yang praktis dan tidak menyita banyak waktu, sehingga toko online banyak diminati oleh konsumen. Dari sisi keuntungan, toko online memiliki banyak kelebihan juga kepraktisan karena tidak memerlukan banyak modal dan promosi. Ecommerce sendiri menurut Ramiza Arvina dan Robert. M diartikan sebagai suatu cara berbelanja atau berdagang secara online atau direct selling yang memanfaatkan internet dengan menggunakan website yang menyediakan fasilitas "get and deliver".

Ruang lingkup e-commerce terbagi menjadi beberapa bagian seperti; pertama, business to business, meruptin akan bisnis komunikasi antar pelaku bisnis atau transaksi secara elektronik antar perusahaan yang dilakukan secara rutin dan dalam kapasitas produk yang besar. Contohnya adalah www.alibaba.com. Kedua, business to customers yang merupakan sistem komunikasi bisnis antar pelaku bisnis dengan konsumen untuk mmenuhi kebutuhan tertentu pada saat tertentu. Contohnya adalah www.ebay.com. Ketiga customer to business yang merupakan individu yang menjual jasa kepada organisasi dan individu yang mencari penjual dan melakukan transaksi. Contohnya adalah pricelline.com. keempat, customers to customers merupakan system komunikasi dan transaksi bisnis antar konsumen untuk memenuhi kebutuhan tertentu pada saat tertentu. Contohnya adalah kaskus.com. 


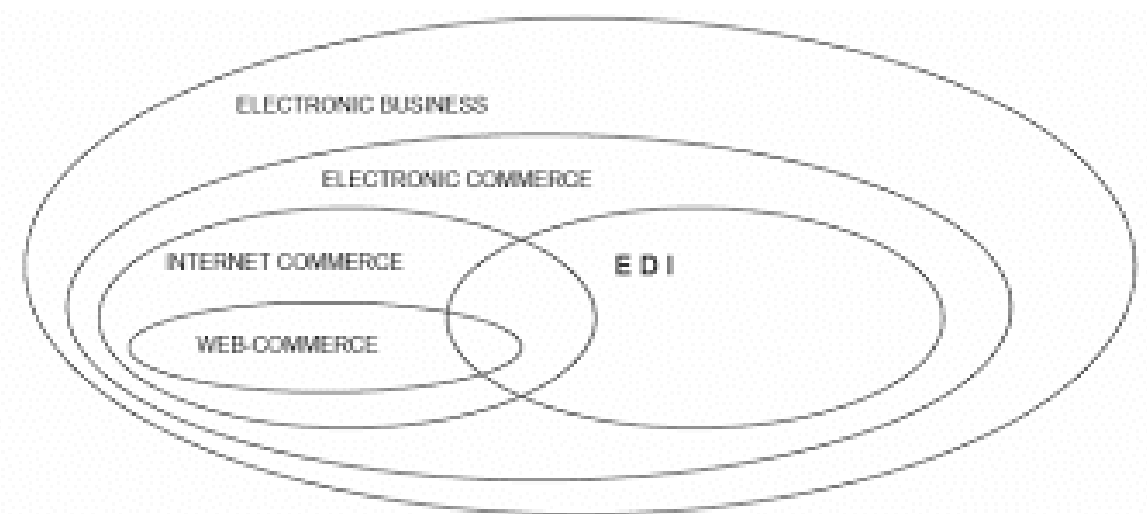

Gambar 1. Ruang lingkup E-Commerce (Susetyorini, 2010)

Dengan adanya e-commerce, suatu organisasi atau perusahaan dapat menjalankan bisnisnya dengan jangkauan yang lebih luas. Terdapat beberapa manfaat e-commerce, seperti kemampuan grafis internet yang mampu memperlihatkan produk apa adanya (natural) serta dapat membuat berbagai fitur layanan promosi dan menyebarkannya tanpa biaya. Kedua, lebih aman membuka toko online dari pada toko offline. Hal ini dikarenakan tidak memerlukan tempat khusus untuk menyimpan stock barang dagangan dan jumlah stok barang dapat disesuaikan dengan pesanan atau permintaan pasar.

Banyak manfaat dari penjualan secara online melalui media internet yaitu dengan adanya e-commerce suatu organisasi atau perusahaan dapat menjalankan bisnisnya untuk menjangkau seluruh Indonesia bahkan sampai ke luar negeri, beberapa manfaat $e$ commerce antara lain sebagai berikut; pertama, kemampuan grafis internet mampu memperlihatkan produk apa adanya (natural) serta dapat membuat brosur berwarna dan menyebarkan tanpa ongkos kirim. Kedua, lebih aman membuka toko online dibanding membuka toko biasa. Hal ini dikarenakan penjual tidak harus memiliki stok barang di tempat tertentu. Ketiga, berjalan di dunia maya internet tidak mengenal hari libur dan hari besar, semua transaksi bisa dilakukan kapan saja dan dimana saja. Keempat, tanpa batas-batas wilayah dan waktu sehingga memberikan jangkauan pemasaran yang luas dan tak terbatas oleh waktu. Kelima, revenue stream (arus pendapatan) yang baru yang mungkin sulit atau dan tidak dapat diperoleh melalui cara konvensial. Keenam, menigkatkan market exposure (pangsa pasar) dimana penggunaan e-commerce memungkinkan untuk meningkatkan pangsa pasar yang semula mempunyai pangsa pasar di dalam negeri saja, dengan adanya e-commerce maka pangsa pasar menjangkau luar negeri. Ketujuh, menurunkan biaya operasi (operating cost).

Penggunaan teknologi internet memungkinkan kita untuk melakukan kegiatan perdagangan selama 24 jam sehari, 7 hari seminggu, akan tetapi tidak terpengaruh terhadap biaya yang dikeluarkan untuk biaya lembur karyawan atau pegawai kerena segala sesuatunya dikerjakan oleh komputer yang tidak membutuhkan operator untuk menjalankan proses perdagangan, cukup hanya dengan penggunaan software tertentu maka semua aktivitas dalam transaksi perdagangan dapat dilakukan. 
Selanjutnya, manfaat $e$-commerce yang lain adalah tidak adanya batasan hari libur dan waktu2 tertentu seperti toko offline, semua transaksi bisa dilakukan kapan saja dan dimana saja. E-commerce juga tidak mengenal batasan waktu dan wilayah, hal ini memberikan jangkauan pemasaran yang luas dan tidak terbatas oleh waktu. Ketiga, revenue stream (arus pendapatan) yang baru dan mungkin sulit untuk didapatkan atau diperoleh melalui cara konvensional. Keempat, melalui e-commerce juga dapat meningkatkan pangsa pasar dimana penggunaan e-commerce memungkinkan untuk menigkatkan pangsa pasar yang semula mempunyai pangsa pasar di dalam negeri saja, dengan adanya e-commerce maka pangsa pasar juga dapat menjangkau luar negeri.

Penggunaan e-commerce juga dapat menurunkan biaya operasi, hal ini dikarenakan kita melakukan perdagangan selama 24 jam sehari, 7 hari seminggu akan tetapi tidak berpengaruh terhadap biaya yang dikeluarkan untuk biaya lembur karyawan atau pegawai. Hal ini dikarenakan segala sesuatunya dikerjakan oleh komputer yang tidak membutukan operator untuk menjalankan proses perdagangan, cukup hanya dengan menggunakan software tertentu maka aktivitas dalam transaksi perdagangan dapat di lakukan. Terdapat beberapa konsep dasar e-commerce, yaitu: Automation: Otomasi bisnis proses sebagai pengganti proses manual (konsep "enterprise resource planning"). Streamlining / Integration: Proses yang terintegrasi untuk mencapai hasil yang efisien dan efektif (konsep "just in time"). Publishing: Kemudahan berkomunikasi dan berpromosi untuk produk danjasa yang diperdagangkan (konsep "electronic cataloging"). Interaction: Pertukaran informasi/data antar pelaku bisnis dengan meminimalisasikan human error (konsep "electronic data interchange"), dan Transaction: Kesepakatan dua pelaku bisnis untuk bertransaksi dengan melibatkan institusi lain sebagai fungsi pembayar (konsep "electronic payment").

E-commerce merupakan satu set dinamis teknologi, aplikasi dan proses bisnis yang menghubungkan perusahaan, konsumen dan komunitas tertentu melalui transaksi elektronik dan perdagangan barang, pelayanan dan informasi yang dilakukan secara elektronik. Layanan e-commerce punya potensi besar di Indonesia, tak ingin industri layu sebelum berkembang 10 perusahaan e-commerce membentuk Indonesian e-Commerce Association (IDEA). Salah satu hal yang juga sangat penting dalam e-commerce adalah SDM (sumber daya manusia). SDM merupakan faktor penentu keberhasilan pelaksanaan $e$ commerce, keterbasan informasi adalah penyebab utama sedikitnya jumlah SDM di Indonesia yang mengerti tentang e-commerce. Masih sedikitnya infrastruktur dan para pelaku e-commerce di Indonesia menjadikan lahan virtual ini akan menjadi lahan yang menjanjikan di masa yang akan datang.

\section{Metode}

Metode yang diaplikasikan untuk kegiatan pelatihan e-commerce ini adalah dengan metode ceramah (presentasi materi) dan praktek (aplikatif). Kegiatan dibagi dalam beberapa tahapan, yaitu pertama, meninjau kondisi masyarakat UMKM (usaha 
masyarakat kecil menengah) di Desa Koto Masjid, Kecamatan XIII Koto Kampar. Kedua, menganalisis proses jual beli yang selama ini berlangsung, apakah efektif atau tidak. Ketiga, memberikan pelatihan tentang e-commerce kepada masyarakat Desa Koto Masjid Kec XIII Koto Kampar. Keempat, melakukan praktik pembuatan akun e-commerce untuk kepentingan bisnis berupa pembuatan toko online, web, blog dan media sosial.

Kegiatan pengabdian ini melibatkan para petani ikan patin sebagai objek pengabdian, adapun jumlah peserta pengabdian yang mengikuti pelatihan adalah sebanyak 45 orang. Subyek kegiatan pengabdian ini adalah pelatihan e-commerce untuk meningkatkan penjualan ikan patin salai dan olahannya. Pelaksanaan kegiatan pengabdian ini pada bulan September tahun 2019. Para petani ikan patin salai dan olahannya diberikan pemahaman dan soft skill tentang e-commerce, serta bagaimana mengemas produk agar menarik dan meningkatkan penjualan serta pangsa pasar yang lebih luas lagi melalui e-commerce.

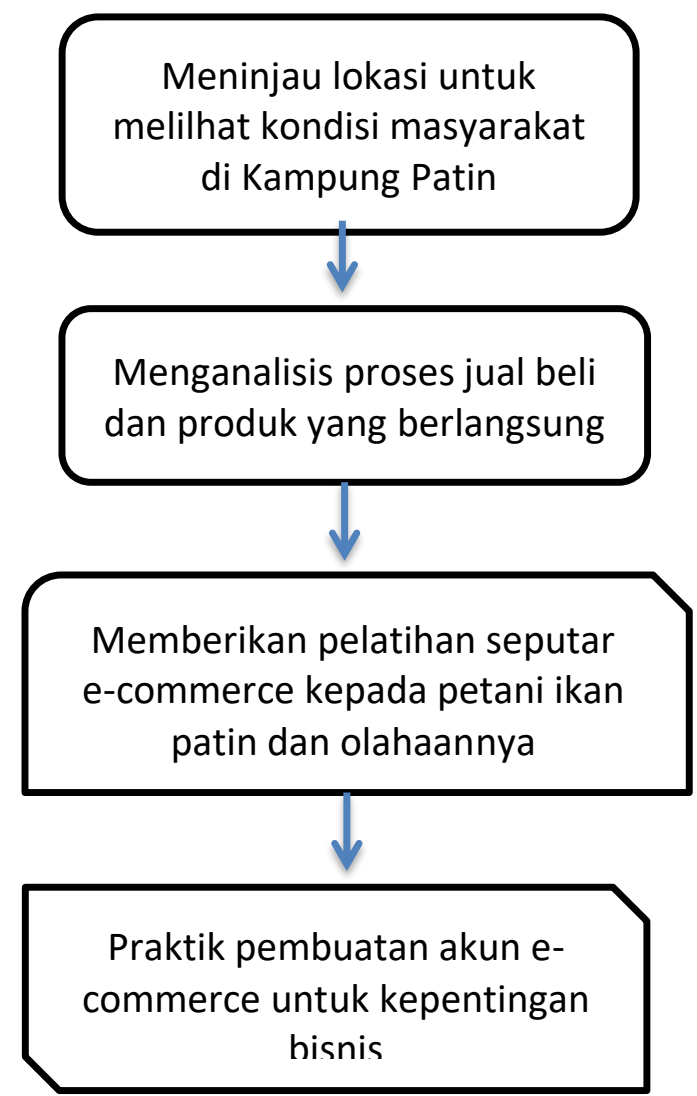

Gambar 2. Metode Pengabdian Masyarakat 


\section{Hasil dan Pembahasan}

Desa Koto Masjid yang terletak di Kecamatan XIII Koto Kampar merupakan desa binaan Telkom yang memiliki motto "tiada rumah tanpa kolam ikan". Pada tahun 1993 masyarakat Desa Koto Masjid adalah masyarakat yang mengikuti program transmigrasi dari desa Batu bersurat. Hal ini dikarenakan desa mereka termasuk desa yang diikutkan dalam program pembangunan PLTA (Pembangkit listrik tenaga air), seihingga pemerintah merelokasi masyarakat ke desa koto masjid untuk kemudian dilakukan program transmigrasi.

Pada mulanya, mayoritas masyarakat mengandalkan hasil dari perkembunan karet, namun karena minimnya pengetahuan dan berbagai hal maka hasil yang diterima tidak sesuai dengan yang diharapkan dan belum dapat mencukupi kebutuhan mereka. Maka dari itu, masyarakat mulai berganti profesi menjadi 61ating61 ikan patin.

Hasil dari usaha ikan patin semangkin baik, hal ini dapat dilihat dari hampir setiap rumah memiliki kerambah atau kolam ikan patin. Ikan patin diolah menjadi ikan patin salai dan berbagai produk olahan yang lain. Walaupun masyarakat sudah berinovasi namun masih terdapat banyak kendala dalam pemasaran produk mereka. Mayoritas masyarakat masih menjual barang dagangan secara manual dari pasar ke pasar, sehingga hasilnya tidak maksimal karena hanya mengandalkan konsumen yang 61ating ke pasar atau yang memesan langsung ke lokasi petani ikan patin.

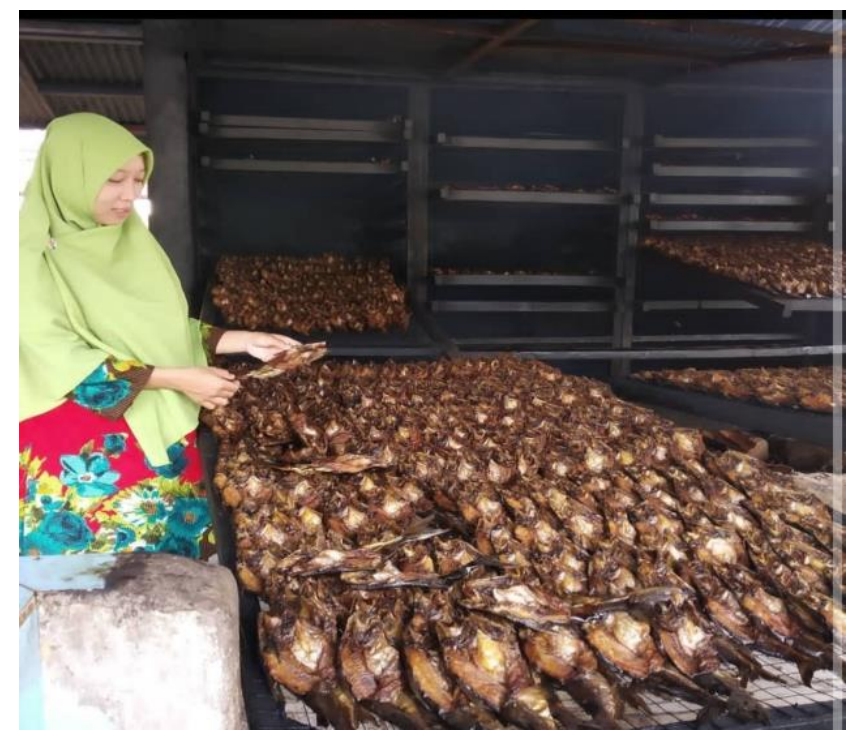

Gambar 3. Salah Satu Produk Olahan Ikan Patin Salai Masyarakat di Desa Koto Masjid Kecamatan XIII Koto Kampar

Kegiatan pengabdian ini terbagi menjadi tiga tahapan, pertama pada tahap ini, tim pengabdi meninjau lokasi pengabdian secara langsung (face to face) dan berdiskusi dengan pemangku kepentingan, seperti perangkat Desa dan masyarakat yang menjadi pegiat usaha ikan patin salai. Dari hasil diskusi ini dapat disimpulkan bahwa masyarakat 
sudah sangat baik dalam pengolahan produk dan terus melakukan inovasi. Hasil ikan patin tidak hanya diolah menjadi patin salai, namun juga produk-produk yang lain seperti bakso patin, nugget patin, abon patin, dan produk olahan patin yang lain. Namun, masih terkendala dalam hal pemasarannya karena masyarakat hanya mengandalakan penjualan secara langsung ke pasar-pasar dan menunggu pesanan yang 62ating untuk kemudian dibuatkan produk yang sesuai dengan pesanana tersebut.

Pada dasarnya masyarakat sangat antusias menyambut pelatihan e-commerce ini karena mereka menyadari bahwa mereka tidak hanya harus berinovasi dalam hal olahan produk yang dijual, namun juga berinovasi dalam hal pemasaran sesuai dengan perkembangan teknologi informasi yang terus mengalami kemajuan. Selama ini masyarakat terkendala dengan pemasaran dikarenakan masyarakat hanya mengandalkan penjualan secara langsung dari pasar ke pasar atau face to face, sehingga pembeli juga terbatas pada orang yang 62ating ke pasar tersebut. Sehingga dibutuhkan inovasi penjualan yang lebih baik dan sesuai dengan perkembangan teknologi yang ada.

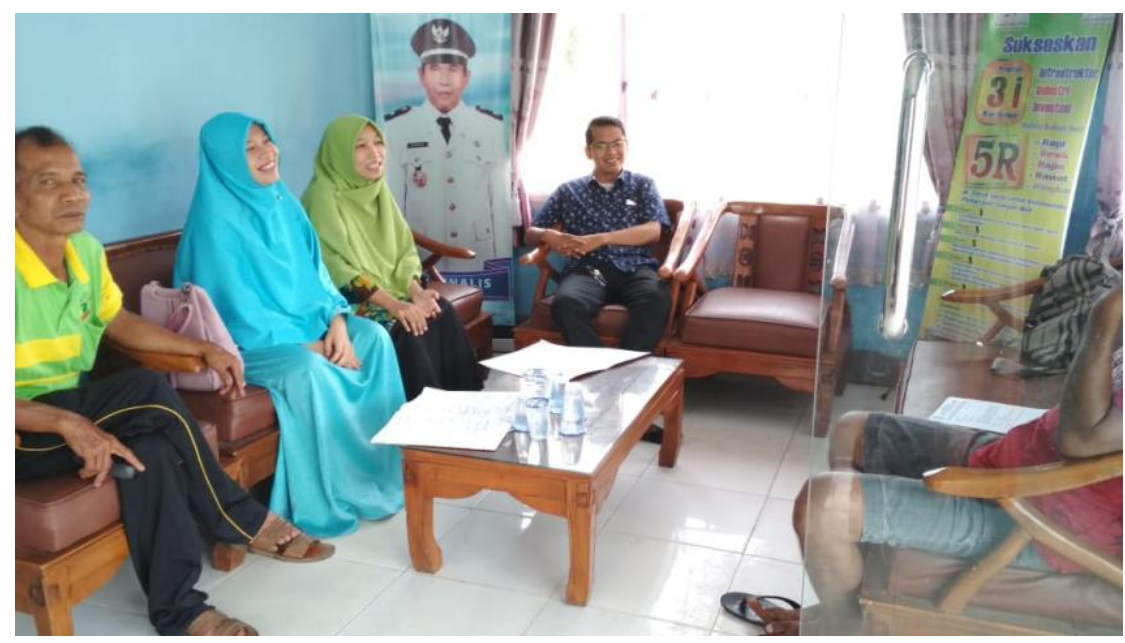

Gambar 4. Kegiatan Tahap Pertama, Identifikasi Masalah

Tahap ke dua adalah tim pengabdi kembali 62ating secara langsung ke lokasi yang berada di Desa Koto Masjid, Kecamatan XIII Koto Kampar. Pelatihan dilakukan di aula kantor desa dan dihadiri oleh pelaku pegiat usaha ikan patin. Adapun peserta yang hadir sekita 40 orang petani ikan patin. Masyarkat diedukasi bagaimana pentingnya teknologi e-commerce atau jual beli online untuk meningkatakan penjualan produk mereka yang seterusnya akan meningkatakan kesejahteraan masyarakat itu sendiri. Masyarakat dilatih bagaimana caranya memanfaatkan media sosial karena media ini adalah media yang gratis tanpa berbayar, seperti menggunakaan facebook dan 62ating62am untuk berjualan produk olahan patin.

Sebagaian masyarakat sudah memiliki akun media sosial, namun belum dimanfaatkan secara baik untuk mempromosikan produk mereka. Selain media sosial, masyarakat juga diedukasi untuk bergabung dengan portal belanja online seperti 
bukalapak dan olx, masyarkat dapat memanfaatkan platform ini untuk menunjang penjualan produk mereka. Selain itu, masyarkat juga diberikan edukasi pengemasan produk yang menarik dan efisien serta murah. Karena kemasan juga sangat mempengaruhi pilihan kosumen untuk memebeli produk yang ditawarkan.

Setelah materi disampaikan kepada masyarakat, maka dilanjutkan dengan sesi diskusi atau tanya jawab antara pemateri dan masyarakat, terdapat umpan balik yang positif dari masyarakast yang mengikuti pelatihan ini. Hal ini dilihat dari banyaknya pertanyaan yang masuk dan keaktifan masyarakat 63ating mengikuti pelatihan. Kegitan ini diharapkan dapat memberikan manfaat dan kontribusi yang nyata bagi masyarkat yang memiliki usaha pengolahan ikan patin di Desa Koto Masjid Kecamatan XIII Koto Kampar.

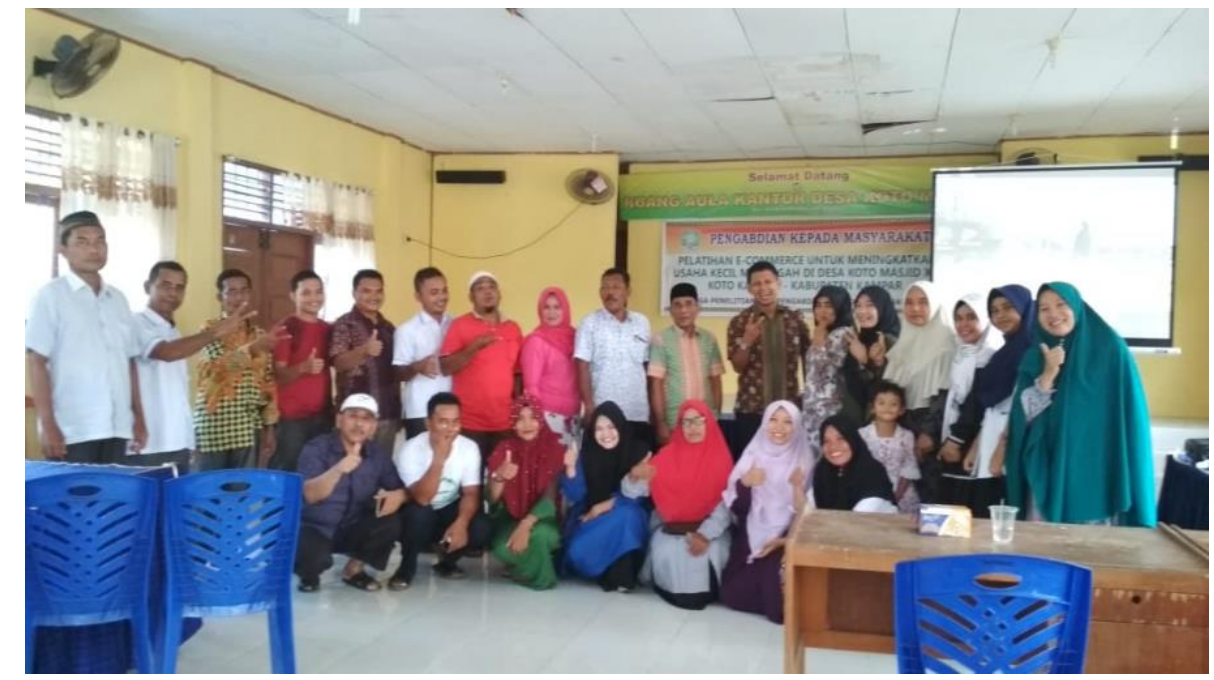

Gambar 5. Sesi Foto Bersama Setelah Penyampaian Materi

Dengan meningkatnya pengetahuan masyarakat tentang e-commerce maka diharapkan masyarakat dapat mempraktekkan secara langsung bagaimana cara dan model penjualan secara online untuk meningkatkan kesejahteraan mereka. Pada tahap kedua ini, dapat disimpulkan bahwa:

1. Memberikan edukasi atau pemahaman kepada masyarakat Desa Koto Masjid yang memiliki usaha pengolahan ikan patin tentang e-commerce.

2. Masyarakat memahami bagaimana cara mengaplikasikan e-commerce untuk menunjang penjualan produk mereka yang pada akhirnya akan meningkatkan kesejahteraan masyarakat.

3. Masyarakat dapat mengaplikasikan e-commerce dari hal yang sederhana yaitu penggunaan media social untuk menjual produk.

4. Masyarakat diedukasi tentang kemasan yang menarik dan higenis sehingga calon pembeli tertarik untuk membeli produk mereka.

5. Masyarakat pegiat usaha pengolahan patin diedukasi untuk bergabung dengan portal belanja online seperti bukalapak dan olx, sehingga jangkauan konsumen dapat lebih luas lagi. 
6. Setelah pemateri selesai, maka diadakan praktik lapangan dan diskusi mengenai kendala di lapangan.

Adapun beberapa kendala yang dihadapi oleh tim pengabdi adalah terbatasnya alat yaitu (laptop atau smartphone), sehingga tidak semua peserta langsung mempraktekkan jual beli secara online. Kegiatan yang tidak sesuai dengan waktu yang ditentukan, hal ini karena masyarakat pada hari tersebut berjualan terlebih dahulu di pasar Bangkinang. Masyarakat tidak ada yang membawa produk untuk kemudian di demonstrasikan. Adapun 64ating penunjang dalam kegiatan ini adalah dukungan dari perangkat desa yang sangat antusias dalam menyambut kegiatan pelatihan e-commerce yang dilakukan oleh tim pengabdi. Masyarakat secara sukarela meluangkan waktu dan tenaganya untuk 64ating ke aula kantor desa guna mengikuti pelatihan tersebut. Ketersediaan alat presentasi yang lengkap berupa proyektor dan laptop serta speaker.

\section{Simpulan}

Mengaplikasikan e-commerce merupakan solusi untuk masyarakat yang memiliki usaha kecil dan menengah. Hal ini dikarenakan jika masyarakat sebagai petani atau pedagang tidak berinovasi, maka tidak akan dapat bertahan di tengah persaingan bisnis yang semangkin berkembang dan mengandalkan teknologi sebagai media jual beli. Petani ikan patin di Desa Koto Masjid Kec. XIII Koto Kampar memiliki potensi yang besar untuk terus berkembang, namun potensi itu harus diiringi dengan inovasi produk dan inovasi penjualan. Memilih e-commerce merupakan pilihan yang tepat bagi para petani ikan patin untuk dapat terus bersaing dan memperluas jangkauan pasar. Setelah dilakukannya pelatihan tentang e-commerce maka diharapkan masyarakat dapat terus mengapliksikan metode e-commerce, sehingga pendapatan masyarakat dapat meningkat. Masyarakat memahami bagaimana mempromosikan produk, mengemas, dan branding produk melalui e-commerce. Masyarakat juga langsung mengaplikasikan e-commerce untuk memperluas pasar dan diharapkan dapat terus konsisten serta pendapatan masyarakat/petani ikan patin salai juga semangkin meningkat.

\section{Referensi}

Amstrong, Gariy, \& Philip, Kotler. (2012). Dasar-dasar pemasaran, Jilid I, Alih bahasa Alexander Sindoro dan Benyamin Molan, Jakarta: Penerbit Prenhalindo

Pradana, Mahir, (2015). Klasifikasi bisnis e-commerce di Indonesia, MODUS Vol. 27 No. 2 H.163-174

Ramli, M. (2012). Usaha pengolahan dan pemasaran ikan salai patin (khusus desa penyesawan kecamatan KamparmRiau. Jurnal Perikanan dan Kelautan Vol.17 No. 2 H.88-105

Susetyorini, Peni. (2010). pelaksanaan elektronik data interchange (EDI) di Pelabuhan Tanjung Emas sebagai alternatif prosedur kepabeanan. Jurnal Pandekta, Vol. 5 No. 2 H. 132-139. 
Wong, Jony, (2010) Internet marketing for beginner, Jakarta: Alex Media Komputindo

Yuni, Irma, (2019). Program pembangunan dan pemberdayaan masyarakat desa (P3MD) di desa pulau gadang kecamtan XIII Koto Kampar. JOM FISIP Vol. 6 Edisi 2 JuliDesember H.1-14.

https://www.jurnal.id/id/blog/jenis-e-commerce-untuk-kembangkan-bisnis/

https://www.riau.go.id/home/content/2019/09/30/8128-peluang-ekspor-patin-dikampar-menjanjikan

https://riau.antaranews.com/berita/125220/mangenal-kampung-patin-di-kabupatenkampar

https://travel.tempo.co/read/1507429/mengenal-kampung-patin-xiii-koto-kampartiada-rumah-tanpa-kolam-ikan-patin 